\title{
Norois
}

Environnement, aménagement, société

$241 \mid 2016$

Innovation sociale et développement des territoires dans les campagnes européennes

\section{Relationships between local governance and local government and the role of the State: evidence from the LEADER programme in Ireland}

Relations entre gouvernance et gouvernement local et le rôle de l'État : le cas du programme LEADER en Irlande

\section{Mary Cawley}

\section{(2) OpenEdition}

\section{Journals}

\section{Electronic version}

URL: https://journals.openedition.org/norois/5991

DOI: 10.4000/norois.5991

ISBN: 978-2-7535-5504-4

ISSN: $1760-8546$

Publisher

Presses universitaires de Rennes

Printed version

Date of publication: 30 December 2016

Number of pages: $33-47$

ISBN: 978-2-7535-5483-2

ISSN: 0029-182X

\section{Electronic reference}

Mary Cawley, "Relationships between local governance and local government and the role of the State: evidence from the LEADER programme in Ireland", Norois [Online], 241 | 2016, Online since 31 December 2018, connection on 13 January 2022. URL: http://journals.openedition.org/norois/5991 ; DOI: https://doi.org/10.4000/norois.5991 


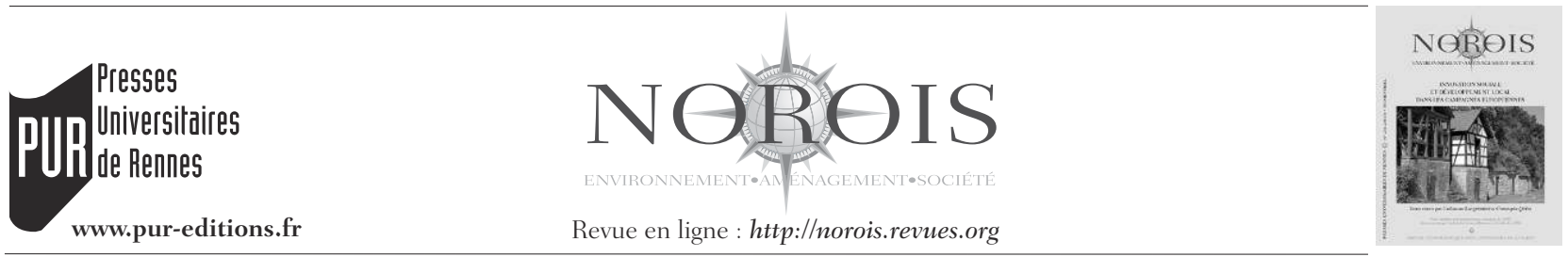

\title{
Relationships between Local Governance and Local Government and the Role of the State: Evidence from the LEADER Programme in Ireland
}

\author{
Relations entre gouvernance et gouvernement local et le rôle de l'État: \\ le cas du programme LEADER en Irlande
}

\author{
Mary CAWLEY \\ Whitaker Institute, School of Geography and Archaeology, National University of Ireland Galway, University Road, \\ Galway, Ireland (mary.cawley@nuigalway.ie)
}

\begin{abstract}
Central states allocated responsibility for local development actions to a range of private, community and voluntary organisations in many European countries, over the past three decades. This phenomenon has been viewed as undermining the roles and influence of local government. In rural areas, the principle of subsidiarity in the LEADER programme was influential in such delegation of responsibilities. This paper has the objective of analysing the changing relationships between local government and local governance associated with LEADER, using Ireland as an example. Ireland assumes particular interest because new governance structures were accompanied in many cases by new territorial areas which did not coincide with the local government county units and LEADER was truly innovative. The method consists of a critical analysis of government policy documents, evaluations of the LEADER programme in Ireland and experience of researching a number of the governance partnerships. The results illustrate the modalities through which local government may gain influence over local governance structures and extend its remits with the support of central government.
\end{abstract}

Résumé : Au cours des trois dernières décennies, les États centraux ont délégué des responsabilités à des organisations privées, communautaires et bénévoles pour le développement d'actions de développement local. Ce phénomène a été perçu comme affaiblissant l'influence et le rôle ou les fonctions des gouvernements locaux (acteurs publics locaux). Dans les zones rurales, le principe de subsidiarité du programme LEADER a influencé l'allocation de telles responsabilités. Ce texte a pour but d'analyser l'évolution des relations, entre les gouvernements locaux et les structures de gouvernance locale, relatives au programme LEADER, en utilisant le cas de l'Irlande comme illustration. L'Irlande présente un intérêt spécifique car le programme LEADER y a été réellement innovant et les nouvelles structures de gouvernance se sont accompagnées, dans de nombreux cas, de la création de nouvelles zones territoriales ne coïncidant pas avec les comtés des gouvernements locaux. La méthode utilisée consiste à établir une analyse critique des documents relatifs à la politique du gouvernement, des évaluations du programme LEADER en Irlande ainsi que des recherches menées sur différents partenariats de gouvernance. Les résultats présentent les modalités à travers lesquelles les gouvernements locaux peuvent étendre plus amplement leur influence sur les structures de gouvernance locale et accroître ses autorités avec le soutien de l'administration centrale.

Keywords: local governance - local government - LEADER - Ireland

Mots clés : gouvernance locale - gouvernement local - LEADER - Irlande 


\section{INTRODUCTION}

"Where government signals a concern for the formal institutions and structures of the state, the concept of governance is broader and draws attention to the ways in which governmental and non-governmental organisations work together and to the ways in which political power is distributed, both internal and external to the state" (Stoker, quoted in Goodwin [1998, 5-6]).

This paper discusses the EU LEADER (Liaison Entre Activités de Développement de l'Economie Rurale) programme as introducing an innovative form of local governance with particular reference to its relationships with local government ${ }^{1}$, using the example of Ireland since 1991. The Irish experience is not entirely unique but the population size and areal extent of local government areas meant that new governance structures and territories emerged in response to the LEADER programme to a greater extent than in some other countries. The evolution of these structures over time has involved interventions by central government and new relationships between the local state and the governance entities. The role of central government in this context has received limited attention in the international literature to date and merits attention. The aims of the paper are: first, to discuss the role of LEADER in introducing a new form of local governance in Ireland with reference to the establishment of new structures and territories for the delivery of the programme; and, second, to examine the evolution of relationships between local governance and local government and the mediating influence of central government. In order to address these aims, a critical evaluation methodology was followed which involved a review of an extensive range of official policy documents and evaluations of the LEADER programme in Ireland since 1991, complemented by experience from researching some of the partnerships.

In order to contextualise the research, key themes relating to tripartite governance are introduced first, namely: (i) the reasons for the creation of new governance structures, their roles and the challenges

1. In Ireland, local government refers to the system of administration in the county or city area. The elected body and its administrative staff are usually referred to as the local authority. However, the terms local government and local authority are sometimes used interchangeably (Callanan, 2003, 3). that may be posed to democratic local government; (ii) partnership as a mode through which new forms of governance operate; (iii) the role of central government in mediating relationships between local governance and local government; and (iv) the innovative features of governance associated with LEADER.

The new modes of governance identified during the last three decades usually involve a tripartite structure of private, community/voluntary, local and central government institutions and agencies working together to meet societal needs (Jessop, 1995). They occur in both urban and rural areas and areabased local actions are central features (Geddes and Beddington, 2001). Such initiatives are often initiated by or supported by central government and arise from at least two broad sets of factors associated with the changing political economy. First, they were established initially as methods of meeting societal needs which states were no longer able to serve adequately, because of reduced budgets, during a period of renewed economic recession in the 1980s (Healey, 2003; Geddes, 2006). Second, as a parallel development, increased attention was being given by neo-liberal states to the devolution of influence to local populations over actions that affect their welfare, to provide greater individualised responsibility (Harvey, 2005; Swyngedouw, 2005). Some commentators view national governments as losing power, particularly to regional bodies through devolution (e.g., Keating, 1998), but they often continued to exercise considerable influence over the actions of the local governance entities (Swyngedouw et al., 2002).

The transition from government to governance by neoliberal governments since the 1980s has been theorised with reference to Foucauldian "neo governmentality" (Brenner et al., 2003). Governmentality relates to the ways in which the state renders the population governable and, in its new form, the distinction between government and population becomes blurred (Woods and Goodwin, 2003). Rose (1996) has referred to a shift from a regime of managed liberalism in the Keynesian welfare state, in which the social sphere (in terms of health, education etc.) was viewed as a legitimate object of governance, managed through state planning at a central level, to one where governing takes place through communities. In the latter context, 
Woods and Goodwin $(2003,254)$ state that "individuals are represented as members of heterogeneous communities of allegiance, through which governance can be organised". These authors also point out that Rose (1996) was referring to any community of interest, not just territorial communities.

The devolution of power to new structures at local levels brought benefits for both the state and local actors, although some commentators have critiqued the trend as eroding the traditional roles of local government in delivering local services (Healey, 2003). In particular the new governance entities were viewed as lacking the democratic legitimacy associated with elected local representatives (Dean, 2010). Swyngedouw $(2005,1992)$ has referred to such "contradictory tendencies" present in new forms of participative governance, versus representative government, as contributing to a "democratic deficit”. There was therefore an inherent possibility for tension between the new forms of governance and local government. The devolution of influence to new governance structures was also accompanied by new "technologies" of governing which relate to associated rules, regulations, methods of oversight and evaluation, and benchmarking of performance (Dean, 2010). They differ from the formally codified rules and procedures of democratic governing and, as such, may be viewed as further evidence of a lesser form of democratic accountability (Hajer, 2003).

"Partnership" was the main modality through which the new tripartite forms of governance operated. Partnership is defined by the OECD (1990, 18) as involving "systems of formalised co-operation, grounded in legally binding arrangements or in formal undertakings, co-operative working relationships and mutually adopted plans among a number of institutions". In the late 1980s, partnership became part of the then European Community's (EC) adoption of "subsidiarity" as a method of promoting involvement in policy-making at the level at which actions are implemented (Turock, 2001). An objective was to "empower" local people through closer engagement in developments that affected their social and economic welfare (Benington and Geddes, 2001; Le Galès, 2002). The formal arrangements associated with the establishment of partnerships and the agreed methods of operating form part of the new technologies of governing.
In some countries the partnerships were based on existing local government structures and territories. In other cases, new structures were established which were not necessarily answerable to local government and were perceived as creating a challenge to its legitimacy (Swyngedouw, 2005). Swyngedouw (2005) points out, however, that the national and the local states and their forms of political organisation and articulation remained important. For example, the central state was usually instrumental in the formation of the new partnership arrangements (Swyngedouw et al., 2002) and has been the originator of local government reform in many European countries during the past two decades (Dollery and Robotti, 2008; Pemberton and Goodwin, 2010). These reforms have implications for relationships with the new governance partnerships and it is pertinent to consider the links between the two. Local government reform was and continues to be driven by several factors, of which two are of particular pertinence here: promoting democracy and gaining budgetary efficiencies (Kersting and Vetter, 2003). On one hand, efforts are taken to increase the involvement of local populations in the local democratic process; for example, by creating new fora for representing their interests. On the other hand, budgetary constraints require that greater efficiencies are gained in the expenditure of public funds through, for example, closer alignment between local governance and local government. Local government reform has taken place within three broad sets of approaches which occur separately and together in various countries (Callanan, 2005). These are liberalism, managerialism and communitarianism. Both managerial and communitarian approaches are apparent in recent local government reform in Ireland (Callanan, 2005; Forde, 2005). Communitarianism was associated in particular with the establishment of a number of Strategic Policy Committees (SPCs) in each county, in 2000, in order to promote greater engagement by local sectoral interests (e.g., the community, environmental, business, trade union, farming, sectors) with elected representatives in longer-term policy and planning at a county level (Callanan, 2005). The roles of the SPCs were strengthened under reforms of local government in 2012-2014 (Quinn, 2015).

The LEADER approach emphasises a role for local partnerships in designing and implementing rural 
development strategies as expressed in the concept of "subsidiarity", i.e. that actions should be planned as close as possible to the level at which they will be implemented (CEC, 2006). The seven key features of LEADER are that: it is area-based; is pursued in a "bottom-up" way; actions are implemented by local public-private-voluntary partnerships known as local action groups (LAGs); an integrated multi-sectoral approach is followed; actions are innovative with true potential for creating additional employment and introducing new economic and social processes and products; co-operation and shared learning take place; and networking takes place between partnerships in order to share good practice. LEADER involves partnerships being responsible for devising and implementing strategies that are jointly funded in substantial ways, by the EU and national governments, with local inputs of finance and/or labour.

The remainder of the paper is structured as follows: first, the role of LEADER in introducing new forms of local governance in Ireland is discussed; second, the results are presented with reference to (i) the relationships between local governance and local government in LEADER and (ii) recent local government reform and its implications for local governance. Conclusions are then drawn.

\section{CONTEXT: LEADER AND INNOVATIVE GOVERNANCE IN IRELAND}

Traditionally, Irish rural policy was sectoral and was designed at a national NUTS 1 (Nomenclature of Territorial Units for Statistics/Nomenclature des Unités Territoriales Statistiques) level primarily by the state departments for agriculture, environment, forestry, fisheries, industry and tourism, among which little collaboration occurred. Delivery took place through regional agencies and their local personnel. Local Government county and city councils $^{2}$ (NUTS 4) in the twenty-six counties of the state (Tablel and Figure 1), had limited responsibilities relating to rural development as such and limited budgets. Their main functions in the early 1990s related to control of physical planning and the supply of public services such as housing, roads, public water provision, sewerage facilities, recreational amenities, technical education and

2. See footnote 1 . libraries. Their remit relating to local enterprise development consisted in providing modest funding and other supports to enterprises that employed less than ten people, through a County Enterprise Board (CEB), but they had a wider role in helping to attract investment to the county by providing the required infrastructure. Their principal sources of income came from rates levied on commercial properties, a registration tax on road vehicles and supplementary funding from central government; one of their main sources of income, private residential property tax, was removed in 1978 (Forde, 2005) (and was reintroduced only in 2013). The LEADER programme promised to compensate for some of the deficiencies in rural service provision. However, many of the Irish counties were larger in area than was considered optimum for integrated area-based actions and had populations that exceeded the 100,000 upper threshold limit envisaged for the delivery of LEADER. New governance and new territorial structures were, therefore, established in many rural areas in response to the call for proposals for LEADER 1, in order to meet the requirements for subsidiarity (Cawley, 2009) (Table 1).

The NUTS 2 Regional Assemblies' roles related primarily to EU funding and programmes in two broad regions. Regional government (NUTS 3), a third administrative tier that is present in many other European countries was also weak in Ireland in the early 1990s and lacked executive power. Closer alignment of rural and regional policy was proposed in a number of government documents (Government of Ireland, 1999 and 2002), but limited progress has taken place in integrating rural and regional policy effectively. The evolution of governance and territorial structures associated with the LEADER programme in Ireland therefore took place mainly in association with central and local government.

The LEADER partnerships in Ireland consisted of three main stakeholder groups: the state/local government sector (public sector agencies, local government), the private sector (farms, banks, local businesses etc.) and the voluntary/community sector (a wide range of local organisations). Ireland is considered to have been particularly successful in the formation of such tripartite partnerships (McDonagh, 2001; Moseley, 2003). There was a long tradition of voluntary associations, formed to compensate for deficits in rural public services, which were able to 


\begin{tabular}{|c|c|}
\hline $\begin{array}{l}\text { Structures (number) and territories } \\
\text { Structures (nombre) et territoires }\end{array}$ & $\begin{array}{l}\text { Functions } \\
\text { Fonctions }\end{array}$ \\
\hline $\begin{array}{l}\text { NUTS } 1 \text { STATE/L'État } \\
\text { Central government departments (16 in September 2016) } \\
\text { Les départements de l'administration centrale }\end{array}$ & $\begin{array}{l}\text { Policy making for areas of legal responsibility in the state } \\
\text { Elaboration des politiques qui concernent leurs responsabilités } \\
\text { juridiques au niveau de l'État }\end{array}$ \\
\hline $\begin{array}{l}\text { NUTS } 2 \text { REGIONS/REGIONS NUTS } 2 \\
\text { Regional Assemblies ( } 3 \text { since 2015) } \\
\text { Les assemblées régionales }\end{array}$ & $\begin{array}{l}\text { Source European funding for Regional Programmes, promote } \\
\text { coordinated public services, monitor proposals which may } \\
\text { impact on the regions, and advise public bodies of the regional } \\
\text { implications of their policies and plans } \\
\text { Procurer les fonds pour les programmes régionaux, favoriser } \\
\text { la coordination des services publics, examiner les propositions } \\
\text { qui peuvent influencer leurs territoires, et conseiller les agences } \\
\text { publiques à propos des implications régionales de leurs politiques } \\
\text { et plans }\end{array}$ \\
\hline $\begin{array}{l}\text { NUTS } 3 \text { SUB-REGIONS/SUB-REGIONS } \\
\text { Strategic Planning Authorities ( } 8 \text { in 2015) } \\
\text { Les autorités pour la planification stratégique }\end{array}$ & $\begin{array}{l}\text { A consultative role for local area input to the Regional Assemblies } \\
\text { Supporter le processus de consultation entre les zones locales et les } \\
\text { Assemblées Régionales }\end{array}$ \\
\hline $\begin{array}{l}\text { NUTS } 4 \text { COUNTIES/COMTES } \\
\text { County councils (26) } \\
\text { Les conseils des comtés }\end{array}$ & \multirow{3}{*}{$\begin{array}{l}\text { Policy making for their geographical areas of responsibility across } \\
\text { a range of functions defined in law } \\
\text { L'élaboration des politiques pour leurs juridictions et leurs } \\
\text { compétences }\end{array}$} \\
\hline $\begin{array}{l}\text { City councils (3, Cork, Dublin, Galway) } \\
\text { Les conseils municipaux }\end{array}$ & \\
\hline $\begin{array}{l}\text { County and city councils (2, Limerick, Waterford since 2014) } \\
\text { Les conseils des comtés et municipaux }\end{array}$ & \\
\hline $\begin{array}{l}\text { Municipal districts in counties other than the three county areas } \\
\text { in Dublin and the three city council areas (95 since 2014) } \\
\text { Districts municipaux dans les comtés, sauf Dublin et les trois zones } \\
\text { des conseils des comtés }\end{array}$ & $\begin{array}{l}\text { The elected members, at the level of the municipal district, have } \\
\text { specific functions for the district defined in law. Other matter of } \\
\text { wider strategic application are generally decided at county level } \\
\text { by the elected members from all municipal districts meeting in } \\
\text { plenary formation } \\
\text { Les membres élus, au niveau du district municipal, ont des } \\
\text { fonctions spécifiques qui sont déterminées juridiquement pour le } \\
\text { district. Les matières qui concernent plusieurs districts sont décidées } \\
\text { en séance plénière au niveau du comté par les membres élus issus } \\
\text { de tous les districts municipaux }\end{array}$ \\
\hline $\begin{array}{l}\text { Local Community Development Committees (LCDCs) (31 since } \\
\text { Le14) } \\
\text { Les Comités Communautaires de Développement Local (CCDL) }\end{array}$ & $\begin{array}{l}\text { A legal function relating to a six-year Local Economic and } \\
\text { Community Plan. Legal functions to improve the coordination } \\
\text { of public-funded local and community development programmes } \\
\text { and reduce duplication } \\
\text { Une fonction légale concernant le plan local économique et } \\
\text { communautaire. D'autres fonctions légales en vue d'améliorer } \\
\text { la coordination des programmes locaux et communautaires qui } \\
\text { reçoivent des financements publics et réduire le double financement } \\
\text { des efforts }\end{array}$ \\
\hline $\begin{array}{l}\text { Local Integrated Development Companies/other entities (38, } \\
\text { 2007-2013) } \\
\text { Les compagnies locales pour le développement intégrélautres entités } \\
\text { Local Development Companies (28 in 2014-2020) } \\
\text { Les Associations de Développement Local }\end{array}$ & $\begin{array}{l}\text { Implementation of LEADER element of EU Rural Development } \\
\text { Programme and community (social) programmes } \\
\text { Mise en œuvre du programme LEADER dans le Programme de } \\
\text { Développement Rural de l'UE et des programmes communautaires }\end{array}$ \\
\hline
\end{tabular}

Table 1: Irish government and governance structures, territories and functions, September 2016 Structures gouvernementales et gouvernance irlandaise : territoires et fonctions, septembre 2016

respond relatively quickly to the first call for proposals for funding (Varley and Curtin, 2006; O'Keeffe 2009 and 2014). In many areas, a co-operative approach was adopted initially by the local authorities and the
LEADER partnerships but tension later arose, in some instances, because the capacity of the latter to operate outside the remit of local government was perceived as a threat (Callanan, 2003). Elected mem- 


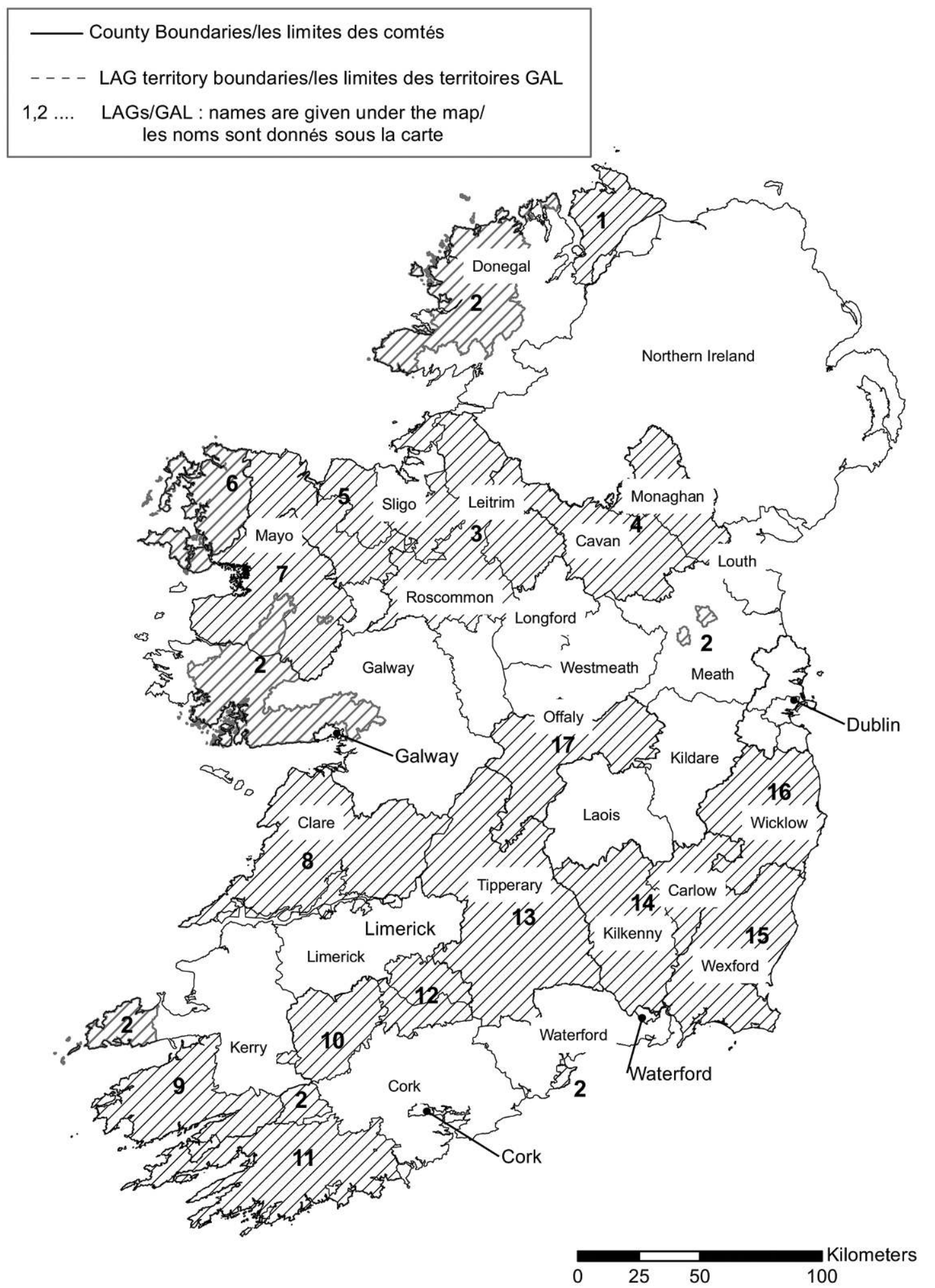

Figure 1: Counties, cities and LEADER 1 areas, Ireland (sources: Ordnance Survey of Ireland, reproduced under licence; Department of Agriculture information relating to LEADER 1 areas; the cities of Dublin, Cork, Limerick, Galway and Waterford are identified; prepared by S. Comer, NUI Galway)

Comtés, villes et Zones LEADER 1 en Irlande (sources: Institut géographique national d'Irlande, reproduit sous licence; renseignements concernant les territoires LEADER 1, fournis par le département de l'agriculture; les cités de Dublin, Cork, Limerick, Galway et Waterford sont identifiées; réalisation S. Comer, NUI Galway) 
bers (councillors) had no automatic right to be represented on the LEADER boards until 2001 and were not necessarily present (CAG, 1999). Research by Moseley et al. (2001) found that where local authorities were involved, they were usually an ordinary partner, represented by an official on a similar basis to other partners. The territories adopted to implement LEADER were based on the formation of the partnerships and there was considerable variation in the areas involved (Figure 1). They included counties (e.g., Wexford, no. 15, and Clare, no. 8), where representation across the county was ensured through substructures or provision for liaison (NESC, 1994). Some large counties contained several LEADER areas (for example, County Mayo, nos. 5, 6, 7) and some partnership areas crossed the boundaries or two or more counties (for example no. 3, which included parts of counties Leitrim, Roscommon and Sligo). The partnership that represented the Gaeltacht (areas defined by statute, where Irish or Gaelic is the first language of a majority of the population) was distributed between areas mainly along the north western, western and south western coasts where the Gaeltacht is located (no. 2). Reflecting the innovative nature of the LEADER approach, many of the geographical territories arose from common interests instead of being based on the county unit.

The formation of new LEADER governance and territorial structures arose as part of the national state's compliance with EU requirements for subsidiarity, associated with the transfer of funds for rural development. The Irish government also, independently, adopted partnership governance in its relationships with employers, trades unions and civil society in order to control wage increases and combat unemployment in the late 1980s (O'Donnell, 2008). Local social area-based partnerships were also formed in urban and rural areas to promote social inclusion and offset unemployment (these are referred to as social partnerships in the discussion to distinguish them from the LEADER groups). Although differing in social and economic emphasis, potential for duplication of applications for funding arose because of the large number of different partnerships (c. 100) that existed in Ireland by the late 1990s (Walsh, 2003). These economic concerns gave rise to questions surrounding efficiency and effectiveness, arising from independent evaluations of the LEADER programme.
The implementation of the LEADER programme was accompanied by technologies of governing relating to the applications for funding, monitoring of expenditure and evaluation of results. LAGs submitted proposals for funding to the government department with responsibility for the programme (the Department of Agriculture initially) (Moseley et al., 2001). Funding was allocated to the partnerships selected which appointed support staff and advertised a call for applications for funding of local projects from individuals and groups, under headings that had been agreed with the EC. These applications were assessed against agreed criteria and decisions were made with regard to those to be funded and the amounts of funding to be granted ${ }^{3}$. Reporting took place to a special monitoring unit in the Department of Agriculture and, during LEADER 1, allocation of even relatively low funds to individual applicants had to be approved by the Department. Accounts were audited by the Office of the Comptroller and Auditor General (CAG, 1999). External ex-ante, interim and ex-post evaluations were conducted by professional evaluators. The formation and operation of the partnerships were also subject to defined rules, the implementation of which became stricter over time. The partnerships enjoyed considerable independence from the local authorities. In fact, it could be said that the LEADER partnerships compensated for the absence of governmental structures below the level of the county, in Ireland. Gradually, however, measures were introduced to bring them within the oversight of the local authorities, beginning in the late 1990s during which time local government reform was also taking place.

\section{Results}

\section{Relationships between local governance and local government in LEADER (1991-2014)}

Ireland has taken part in all five phases of the LEADER programme to date. The amounts of funding granted and the numbers of LAGs involved changed over time, as did the relationships with local government (Table 2).

\footnotetext{
3. This paper does not deal with the practical outcomes of the investment that took place through the Leader programme in terms of business formation, job creation, training in skills and local area enhancement, which are documented elsewhere (e.g. Storey, 1999; Moseley et al., 2001; Dax et al., 2013).
} 


\begin{tabular}{|c|c|c|}
\hline $\begin{array}{l}\text { Programming period } \\
\text { Période de programmation }\end{array}$ & $\begin{array}{l}\text { Number of LAGs to implement } \\
\text { LEADER partnerships (total fun- } \\
\text { ding) } \\
\text { Nombre de GAL à fin de mise en } \\
\text { oeuvre le programme LEADER ( } \mathrm{f} \text { - } \\
\text { nancement total) }\end{array}$ & $\begin{array}{l}\text { Relations with local government } \\
\text { Relations avec les gouvernements locaux }\end{array}$ \\
\hline 1991-1994 & $16(44.8 €$ millions $)$ & $\begin{array}{l}\text { Representation of local government by ordinary members on cer- } \\
\text { tain LEADER committees } \\
\text { Représentation du gouvernement local par des membres ordinaires } \\
\text { dans certains comités LEADER }\end{array}$ \\
\hline 1995-1999 & 32 (95.58€ millions) & $\begin{array}{l}\text { Creation of County Development Boards (CDBs), in 1999, to } \\
\text { which the LEADER partnerships were required to report } \\
\text { Création des Conseils de développement des comtés (CDB) en } \\
\text { 1999, auxquels les partenariats LEADER doivent rendre leurs rap- } \\
\text { ports }\end{array}$ \\
\hline $2000-2006$ & $\begin{array}{l}22 \text { jointly financed by the EU-Ire- } \\
\text { land and } 16 \text { financed by the Irish } \\
\text { government ( } 98.23 € \text { millions) } \\
22 \text { financés conjointement par l'UE- } \\
\text { Irlande et } 16 \text { financés par le gouver- } \\
\text { nement irlandais }(98,23 \text { millions } \\
\text { d'€) }\end{array}$ & $\begin{array}{l}\text { Henceforth the annual plans of the LEADER partnerships must } \\
\text { be approved by the CDBs } \\
\text { Les CDB ont alors dî donner leur approbation quant aux plans } \\
\text { annuels des partenariats LEADER } \\
\text { from } 2001 \text {, each county council had the right to be represented, } \\
\text { by elected members, on the LEADER partnerships in the county } \\
\text { Après } 2001 \text {, chaque conseil de comté avait le droit d'être représenté, } \\
\text { par des élus, dans le comité des partenariats LEADER dans le comté }\end{array}$ \\
\hline $2007-2013$ & 38 (425€ millions) & $\begin{array}{l}\text { Integrated Local Development Companies (ILDCs) were crea- } \\
\text { ted by merging the LEADER and the social partnerships in most } \\
\text { counties } \\
\text { Fusion des partenariats LEADER et sociaux comme Entreprises } \\
\text { pour le développement local intégré, selon les différents comtés }\end{array}$ \\
\hline $2014-2020$ & 28 (250€ millions) & 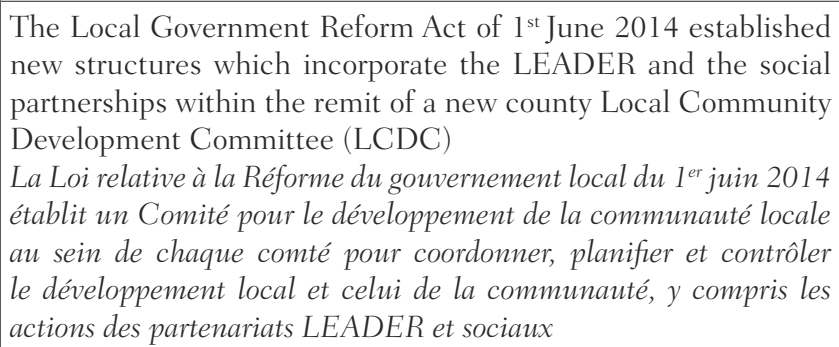 \\
\hline
\end{tabular}

Table 2: The evolution of the LEADER programme in Ireland, 1991-2014, and relations established with local government Évolution (1991-2014) du programme LEADER en Irlande et relations avec les gouvernements locaux

Sixteen LAGs were funded under LEADER 1, 1991-1994, covering approximately $60 \%$ of the land area of the Irish state (Kearney and Associates, 1997). Thirty six LAGs were recognised and funded under LEADER 2, 1995-1999, and covered all counties in the state, excluding cities, reflecting the success of local groups in preparing proposals approved for funding (Storey, 1999). As in LEADER 1 , some territories coincided with the county areas, some counties contained more than one partnership and some cross-county partnerships existed. An evaluation of LEADER 1, suggested that there was a possibility of projects applying for funding from both LEADER and the social partnerships and/or the CEB (Kearney and Associates, 1997). However, where funding was obtained from more than one source, the total amount did not exceed that permitted under the LEADER regulations. In order to avoid duplication of funding, the government transferred responsibility for economic initiatives from the social partnerships to the LEADER partnerships in 1994 (Cawley, 2007).

As LEADER 2 came towards an end, concerns were expressed about a democratic deficit among the membership of the management boards of LEADER and the social partnerships (Walsh, 
2003) - an issue identified by Sywngedouw (2005) as potentially problematic in the case of new governance partnerships. Most of the members represented sectional interests and were not elected by universal franchise among the population in general, as are county councillors (councillors were not permitted to become members of the social partnerships until 2001). In response to these concerns, the government required the LAGs to liaise with a County Development Board (CDB), established in each county in 1999, as part of a local government communitarian reform initiative to enhance representation (Government of Ireland, 1998). This measure also served to keep the local authorities more aware of the activities being pursued by the partnerships. Evidence of competition between some CEBs and the LEADER partnerships for high quality projects, during LEADER 2, also suggested that greater collaboration was necessary.

The LEADER + programme ran between 2000 and 2006. Twenty two LAGs with well-developed proposals were funded jointly by the EU and the national government and 16 with less strong proposals were funded by the Irish government solely, made possible by the increased availability of funding as the economy grew strongly (Fitzpatrick Associates, 2005) (Table 2). In 2002, responsibility for rural development was moved from the Department of Agriculture to a new Department of Community, Rural and Gaeltacht Affairs (DCRGA), reflecting the special attention being given to the rural community sector.

Almost immediately, the responsible minister commissioned a review of expenditure by the LAGs in order to secure the most positive impacts for local communities from the EU Rural Development Programme (RDP) 2006-2013, in which LEADER actions were to be incorporated with agriculture. Concerns were expressed in the expenditure review about duplication of actions and investment between the social partnerships and the LEADER LAGs, notwithstanding the measures that had been taken to avoid such duplication in 1994. Further integration of the LEADER and the social partnerships was envisaged as a method of gaining economic efficiencies as part of a process of "cohesion". In August 2007, the Minister announced (prematurely, as it transpired) that he had obtained agreement that 25 new Integrated Local Development Companies
(ILDCs), incorporating the LEADER and the social partnerships, would be established on a county basis in rural areas across the state (DCRGA, 2007). This proposal evoked a negative response from some of the various groups involved, which did not consider that satisfactory consultation had taken place. Following further discussion, the Minister agreed that 37 ILDCs would be established. By July 2009 (two years after the RDP was scheduled to commence), 25 ILDCs were in place, based on partnerships which already collaborated in delivering social and economic programmes, and 12 additional companies were formed through mergers (Table 3 traces the experience in one county).

In practice, more than one entity implemented the RDP in the larger counties of Cork, Donegal, Galway, Kerry, Limerick and Mayo (Figure 2). The offshore islands formed a 38th partnership.

The ILDCs strengthened the links to the local authorities and the county territories. The boards of the new development companies were to include four elected councillors and a nominee of the County Manager and were required to have their annual plans endorsed by the CDB in each county. This latter requirement and a requirement for further budgetary reporting to the DCRGA involved additional administration for both the local authorities and the partnerships, especially where a county boundary was crossed. There were, however, many examples of LAGs and local authorities working productively together in village enhancement projects, for example. In response to new EU strategic guidelines for rural development for 2007-2013 (CEC, 2006), relating to greater inclusion of marginalised groups, the ILDC boards increased their membership from the community and voluntary sectors and from minority groups (e.g., youth, women, immigrants). Notwithstanding efforts to promote further democratic representation and efficiencies through the merging of partnerships and closer relationships with local government, an evaluation conducted for the EC identified several weaknesses in the implementation of the RDP 2007-2013 in Ireland (Dax et al., 2013). These included delays in beginning the work of the programme, as a result of the delays with mergers, and additional time required for budgetary reporting to the DCRGA. It was found that agriculture-related projects took precedence over other projects, arising from LEADER being 


\begin{tabular}{|c|c|}
\hline Leader 1 1991-1994 & \\
\hline $\begin{array}{l}\text { Arigna Catchment Area Community Company (ACACC) had } \\
\text { responsibility for County Leitrim, north County Roscommon } \\
\text { and a part of County Sligo (Fig. 1, area 3) } \\
\text { La Compagnie Communautaire pour la Région d'Arigna gérait le } \\
\text { comté de Leitrim, le nord du comté de Roscommon et une partie } \\
\text { du comté de Sligo }\end{array}$ & $\begin{array}{l}25 \text { Directors represented the community, local government, } \\
\text { public sector agencies, regional tourism organisations } \\
25 \text { administrateurs représentaient la communauté, le gouverne- } \\
\text { ment local, les agences publiques et les organismes régionaux du } \\
\text { tourisme }\end{array}$ \\
\hline Leader 2 1995-2000 & \\
\hline $\begin{array}{l}\text { As in Leader I } \\
\text { Comme pour Leader I }\end{array}$ & $\begin{array}{l}\text { County Leitrim Partnership (CLP) established in } 1996 \text { in res- } \\
\text { ponse to the EU-funded Operational Programme for Local } \\
\text { Urban and Rural Development to deliver a Local Development } \\
\text { Social Inclusion Programme (LDSIC) } \\
\text { L'Association du Comté de Leitrim (CLP) fut créée en } 1996 \text { en ré- } \\
\text { ponse au Programme Opérationnel pour le Développement Local } \\
\text { Urbain et Rural qui était financé par l'EU pour la mise en ceuvre } \\
\text { du Programme Local de Cohésion Sociale } \\
16 \text { directors represented the community, public sector agencies } \\
\text { and the social partners } \\
16 \text { administrateurs représentaient la communauté, les agences } \\
\text { publiques et les partenaires sociaux }\end{array}$ \\
\hline Leader + 2001-2006 & \\
\hline $\begin{array}{l}\text { As in Leader I and II } \\
\text { Comme pour Leader I et II }\end{array}$ & $\begin{array}{l}\text { CLP delivered EU and Irish social employment and other social } \\
\text { programmes in County Leitrim } \\
\text { Le CLP met en oeuvre les programmes pour l'emploi et autres pro- } \\
\text { grammes sociaux, européens et irlandais, dans le comté de Leitrim }\end{array}$ \\
\hline Rural Development Programme/Le programme de développeme & nt rural 2007-2013 \\
\hline $\begin{array}{l}\text { Leitrim Integrated Development Company established, Decem- } \\
\text { ber 2007, through merger of ACACC and CLP, to deliver Lea- } \\
\text { der and social programmes in County Leitrim } \\
\text { La Compagnie pour le Développement Intégré de Leitrim fut créée } \\
\text { en décembre 2007, suite à la fusion de l'ACACC et du CLP, afin } \\
\text { de mettre en œuvre le programme Leader et des programmes so- } \\
\text { ciaux dans le comté de Leitrim }\end{array}$ & $\begin{array}{l}23 \text { directors represented community, local government, public } \\
\text { sector agencies and the social partners } \\
23 \text { administrateurs représentent la communauté, le gouvernement } \\
\text { local, les agences publiques et les partenaires sociaux }\end{array}$ \\
\hline Rural Development Programme/Le programme de développeme & nt rural 2014-2020 \\
\hline $\begin{array}{l}\text { Leitrim Development Company is the implementing partner for } \\
\text { Leader - on behalf of the local action group } \\
\text { L'Association de Développement de Leitrim est le partenaire res- } \\
\text { ponsable du programme Leader, pour le compte du groupe d'action } \\
\text { locale } \\
\text { Leitrim Local Community Development Committee (a commit- } \\
\text { tee of Leitrim local government) } \\
\text { Le Comité pour le Développement Communautaire Locale de Lei- } \\
\text { trim (un comité du gouvernement local de Leitrim) }\end{array}$ & $\begin{array}{l}17 \text { directors representing the community, local government, } \\
\text { public sector, social partners and the private sector ( } 9 \text { director } \\
\text { from the non-statutory sector) } \\
17 \text { administrateurs représentent la communauté, le gouvernement } \\
\text { local, les agences publique, les partenaires sociaux et le secteur } \\
\text { privé ( } 9 \text { administrateurs représent le sector non-statutaire) }\end{array}$ \\
\hline
\end{tabular}

Table 3: County Leitrim: an example of changing governance structures, responsibilities and territories between 1991 and 2014 (sources: CLP, 1996, 28; ACACC 1997; Pobal, 2007, 145; Interview with Manager of Arigna LEADER 1998; Leitrim Integrated Development Company [2007]; Leitrim Business.ie [2016])

Le comté de Leitrim, exemple des changements dans les structures de gouvernance, les compétences et les territoires entre 1991 et 2014 - entretien avec l'administrateur d'Arigna, LEADER, 1998 


\section{County Boundaries/les limites des comtés \\ - - - LAG territory boundaries/les limites des territoires GAL \\ 1,2 .... LAGs/GAL : names are given under the map/ les noms sont donnés sous la carte}

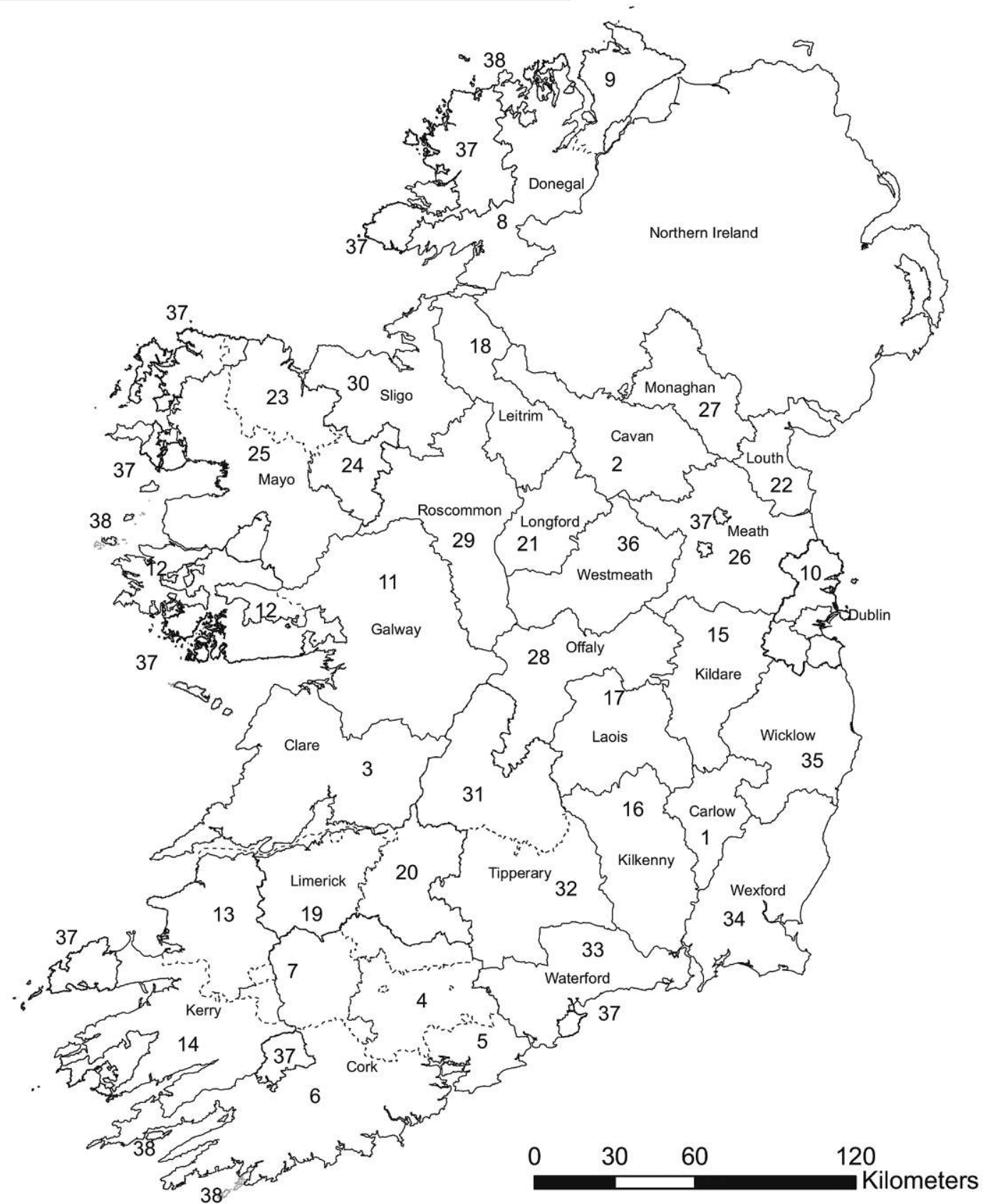

Figure 2: Rural Development Programme (RDP) 2006-2013, Counties and other operational areas, Ireland (sources: Ordnance Survey of Ireland, reproduced under licence; [http://enrd.ec.europa.eu/enrd-static/leader/local-action-groups/en/local-action-groups_ en.html?country=Ireland] and GAMMA, Dublin, for RDP areas 2006-2013; prepared by S. Comer, NUI Galway)

Le Programme de Développement Rural (PDR) 2006-2013, Comtés et autres zones opérationnelles en Irlande (sources: Institut géographique national d'Irlande, reproduit sous licence; renseignements concernant les territoires PDR 2006-2013, enrd.ec.europa.eu et GAMMA, Dublin; réalisation S. Comer, NUI Galway) 
integrated with agricultural policy. There was also little evidence of the "new rural paradigm" based on local territory, as recommended by an OECD (2006) report.

\section{Recent local government reform and the implications for local governance}

The review of the evolving relationship between local governance and local government illustrates that change at a local scale was influenced by decisions made by responsible government ministers centrally, in response to both national priorities and changing EU policy ${ }^{4}$ (e.g., decisions relating to cohesion and broader representation). The focus here is on the quest for greater democratic representation and efficiencies in public expenditure which were pursued as part of local government reform. Over time, the elected local representatives became increasingly suspicious of the influence of the LEADER partnerships and the erosion of their clientelist role and appealed to the argument of a 'democratic deficit' in seeking to increase their own influence over LEADER (Callanan, 2003; Swyngedouw, 2005). They were also losing influence to central government, through a reduced role in the delivery of a range of public services, including health services and public water supply (from 2015 on) and their budgets remained constrained (O’Keeffe, 2009). Since the early 1990s, central government had sought methods of reducing the cost and increasing the efficiency of local government service delivery. Bringing local governance within the remit of local government was one of the ways of attaining these aims and, at the same time, compensating for some of the responsibilities that had been removed from the latter.

Following the election of a new government in 2011, responsibility for LEADER was allocated to the new Department of the Environment, Community and Local Government (DECLG), highlighting the growing links between governance and local government. A review of the RDP 2007-2013 programme by a government-appointed Local Government/Local Development Alignment Steering Group (referred to

4. It is recognised that the evolution of local governance in LEADER took place within the context of policy change at an EU level. The details of the relationships between national government policy and EU policy are beyond the scope of this paper. hereafter for simplicity sake as the Steering Group), published in March 2012, identified limitations associated with the model for integrating the social and LEADER partnerships introduced in 2007 (DECLG, 2012a). These were said to include: their considerable administrative burden; the potential for duplication and overlap between activities because of the many organisations involved; the multiple arrangements for funding and reporting; and the demands and hidden costs associated with the requirement to participate in multiple boards and structures at local level. It was further pointed out that, in general, local government authorities have limited input into strategy or decision-making with respect to local development programmes and that their involvement should be increased. The methods of gaining efficiencies included a sharing of office facilities and services between local authorities and LAGs, and oversight of local and community development programmes by a special committee at a county level, i.e. to integrate the activities of the LAGs and social partnerships with those of the local authorities (DECLG, 2012a). It was recommended that an Inter-Departmental Group be established at a national level to enhance data capture across various programmes and gain efficiencies in expenditure by avoiding the possibility of duplication. Thus, the LAGs were to be brought within closer control of local government through "territorial alignment" and of national government through a "whole government approach" (ibid., 13).

The Steering Group proposals were incorporated into an Action Plan for More Effective Local Government (DECLG, 2012b). The Local Government Reform Act of 1 June 2014 (Government of Ireland, 2014) gave legal effect to the increased influence being allocated to local government in economic and social development, through the establishment of a Local Community Development Committee (LCDC) in each county to replace the former CDB. The membership represents a wide range of public, community and civic society interests in a communitarian approach. There are elements of managerialism involved, however. The LCDC has a statutory (legal) function relating to the preparation of a six-year Local Economic and Community Plan, its implementation, review, monitoring and revision if necessary (DECLG, 2014). It has statutory functions also to improve the coordination of public-funded local and community development programmes 
and reduce duplication (ibid.). An almost immediate public protest followed from members of the LAGs and the social partnerships to the establishment of the LCDCs and the wide-ranging powers allocated to them with respect to local development (Holland, 2014; ILDN News, 2014a).

Particular concerns expressed by the LAG boards concerning the delivery of the RDP 20142020 relate to the reduction of $41 \%$ in the overall LEADER budget, as compared with 2007-2013, and the lower government support for LEADER than for agriculture (ILDN News, 2014a). The allocation of responsibility for LEADER to the local authorities will lead, it was felt, to the loss of experienced staff and of the voluntary contributions of members of the management boards (ILDN News, 2014b). Further, local authorities may not be permitted to access philanthropic funds, to supplement funding from the EU and the national government, as the LAGs have been able to do in the past (ILDN News, 2014c). In September 2016 it was announced that "Ireland's LEADER programme will encompass 28 sub-regional areas" (DAFM, 2016, 34-35).

\section{Conclusions}

Responsibility for local development and service delivery has been given to new public-private-voluntary partnerships, in both urban and rural areas in many countries since the 1980s, in a form of neo-governmentality (Brenner et al., 2003). The benefits have involved the devolution of greater influence to local communities over actions that affect their wellbeing and the creation of a sense of ownership and empowerment (OECD, 2006). Negative features have been associated with undermining the role of local government (Swyngedouw, 2005). There is a tension between new forms of participative democracy and representative democracy and the latter may seek to recover its perceived loss of influence. Local government reform, designed to increase democratic engagement and gain financial efficiencies, has also been in progress during the same period of time, often initiated by central governments, with implications for the relationships between new forms of governance and local government. This paper addressed these relationships in the context of Ireland.

The EU LEADER programme was considered as being particularly innovative in Ireland, given a highly centralised system of government and limited financial resources that could be deployed for rural development at a local government level. In order to meet the LEADER requirement for subsidiarity, new LAG governance structures and new territorial units became responsible for its implementation. In several instances they diverged from the existing county structures and, in general, had considerable independence from the local government authorities, although often working with them on particular projects. Social partnerships were also established in Ireland to promote inclusion and offset unemployment. By the late 1990s, there was a proliferation of governance entities operating within various geographical areas with limited links with local government. Evaluations that were conducted as part of the technologies of governing identified a democratic deficit in representation and some duplication of funding and effort. Remedial measured were introduced by central government to promote greater integration which were imbricated with measures for local government reform. Increased representation of local interests in new local government structures was provided in a spirit of communitarianism (Callanan, 2005) but there were also strong elements of managerialism in the actions taken by the Irish government (Forde, 2005). Managerialism has become more pronounced in the reforms introduced in 2014 which appear to undermine the subsidiarity associated with LEADER.

The evidence illustrates that the new forms of governance associated with the LEADER approach may successfully promote public participation, beyond the traditional remit of local government, as well as promoting economic development. However, the democratic representative role of local government confers particular capacities to respond to any perceived undermining of its influence. In the Irish case, after an initial liberal approach to the formation of governance structures, in order to deliver a range of local services with EU funding support and limited involvement of local government, central government supported closer alignment with the latter. This support has been promoted as part of the communitarian pursuit of greater democratic representation combined with managerial intervention, designed to gain efficiencies in public expenditure through coordination and oversight within the context of the local government county structure. 


\section{Bibliography}

ACACC (Arigna Catchment Area Community Company Ltd.). 1997. Arigna LEADER report and accounts 1996-1997, Arigna, ACACC.

Benington J., Geddes M., 2001. Social exclusion, partnership and local governance - new problems, new policy discourses in the European Union, in Geddes M., BeningTON M. (dir.), Local partnerships and social exclusion in the European Union, London, Routledge, p. 1-14.

Brenner N., Jessop B., Jones M., McLeod G., 2003. Introduction: state space in question, in Brenner N., Jessop B., Jones M., MacLeod G. (dir.), State/space: a reader, Oxford, Blackwell, p. 1-26.

Callanan M., 2003. Local government and the European Union, in Callanan M., Keogan M.F. (dir.), Local government in Ireland: inside out, Dublin, Institute of Public Administration, p. 404-428.

Callanan M., 2005. Institutionalizing participation and governance? New participative structures in local government in Ireland, Public Administration, vol. 83, n 4, p. 909-929.

CAwley M., 2007. Rural development in Ireland: a local governance perspective, in Hodgett S., Johnson D., Royle S. (dir.), Doing development differently: regional development on the Atlantic periphery, Sydney, Nova Scotia, Cape Breton University Press, p. 246-266.

Cawley, M., 2009. Local governance and sustainable rural development: Ireland's experience in an EU context, Revija za Geografijo, vol. 7, no 1, p. 53-64.

CEC (Commission of the European Communities), 2006. The LEADER approach: a basic guide, Brussels, CEC, 23 p.

CAG (Comptroller and Auditor General), 1999. Report on value for money examination, local development initiatives, Dublin, Government Publications, 20 p.

CLP (County Leitrim Partnership), 1996. Area action plan 1996-1999, Drumshanbo, CLP, 29 p.

Dax T., Strahl W., Kirwan J., Maye D., 2013. The LEadeR programme 2007-2013: enabling or disabling social innovation and neo-endogenous development? Insights from Austria and Ireland, European Urban and Regional Studies, early view.

[http://eur.sagepub.com/content/early/2013/07/25/09697764134 90425], accessed 18 March 2014.

DeAn M., 2010. Governmentality: power and rule in modern society, London, Sage, $2^{\text {nd }}$ ed., 294 p.

Department of Agriculture, 2007. Ireland, CAP rural development programme 2007-2013, Dublin, Department of Agriculture, $501 \mathrm{p}$.

DAFM (Department of Agriculture, Food and the Marine), 2016. 2016 Summary of Rural Development Programme, Ireland, 2014-2020, Dublin, DAFM, 54 p.

DCRGA (Department of Community, Rural and Gaeltacht Affairs), 2007. Guidelines on the governance of integrated local development companies and urban based partnerships, Dublin, DCRGA, 63 p.

DECLG (Department of Environment, Community and Local Government), 2012a. Final report of the local govern- ment/local development alignment steering group, Dublin, DECLG, 58 p.

DECLG (Department of Environment, Community and Local Government), 2012b. Putting people first: action programme for effective local government, Dublin, DECLG, 198 p.

DECLG (Department of Environment, Community and Rural Government), 2014. Guidelines for the establishment and operation of Local Community Development Committees, Dublin, DECLG, 43 p.

DHPCLG (Department of Housing, Planning, Community and Local Government), 2016a. Local government reform, [http://www.housing.gov.ie/local-government/reform/localgovernment-reform], downloaded 21 September 2016.

DHPCLG (Department of Housing, Planning, Community and Local Government), 2016b, Local Community Development Committees. [http://www.housing.gov.ie/community/ alignment/alignment-local-government-local-development], downloaded 21 September 2016

Dollery B., Roвotti L. (dir.), 2008. The theory and practice of local government reform, Cheltenham, Edward Elgar Publishers, 315 p.

Fitzpatrick Associates, 2005. Mid-term evaluation of LEADER+, Phase 2 Report, Dublin, Fitzpatrick Associates, 50 p. + Appendices, $10 \mathrm{p}$.

Forde C., 2005. Participatory democracy or pseudo-participation? Local government reform in Ireland, Local Government Studies, vol. 31, n 2, p. 137-148.

Geddes M., 2006. Partnership and the limits to local governance in England: institutionalist analysis and neoliberalism, International Journal of Urban and Regional Research, vol. 30, n 1, p. 76-97.

Geddes M., Benington M. (dir.), 2001. Local partnerships and social exclusion in the European Union: new forms of local social governance, London, Routledge, 254 p.

Goodwin M., 1998. The governance of rural areas: some emerging research issues and agendas, Journal of Rural Studies, vol. 14, n ${ }^{\circ} 1$, p. 5-12.

Government of Ireland, 1998. Task force on the integration of local government and local development systems, Report, Dublin, Government Publications, 18 p.

Government of Ireland, 1999. White paper on rural development, Dublin, Government Publications, 56 p.

Government of Ireland, 2002. National spatial strategy 20022020: people, places and potential, Dublin, Government Publications, $152 \mathrm{p}$.

Government of Ireland, 2014. Local Government Reform Act, No. 1 of 2014. [http://www.irishstatutebook.ie/pdf/2014/ en.act.2014.0001.pdf], accessed 30 September 2014.

Hajer M., 2003. Policy without polity? Policy analysis and the institutional void, Policy Sciences, vol. 36, n 2, p. 175-195.

Harvey D., 2005. Neoliberalism: a short history, Oxford, Oxford University Press, 247 p.

Healey P., 2003. Institutionalist theory, social exclusion and governance, in Madanipour A., Cars G., Allen J. (dir.), Social exclusion in European cities, London, Jessica Kingsley, p. 53-73. 
Holland K., 2014. Thousands protest against plan to change LEADER schemes, The Irish Times, 9th July 2014. [http:// www.irishtimes.com/news/social-affairs/thousands-protestagainst-against-plan-to-change-leader-schemes-1.1860899], accessed 23 April 2015.

ILDN (Irish Local Development Network) News, 2014a. Local development companies express concerns over local government reforms, 7 March 2014. [http://ildn.ie/news/2014/03], accessed 23 April 2015.

ILDN (Irish Local Development Network) News, 2014b. Galway companies express concerns over local government reform, 27 March 2014. [http://ildn.ie/news/2014/03], accessed 23 April 2015.

ILDN (Irish Local Development Network) News, 2014c. What do local government reforms mean for rural communities? 11 March 2014. [http://ildn.ie/news/2014/03], accessed 23 April 2015.

JEssop B., 1995. The regulation approach, governance and postFordism: alternative perspectives on economic and political change? Economy and Society, 24, n 3, p. 307-333.

Kearney and Associates, 1997. LEADER I initiative in Ireland: report on final outcome of LEADER I, Dublin, Kearney and Associates, $46 \mathrm{p}$.

Keating M., 1998. The new regionalism in Western Europe: territorial restructuring and political change, Cheltenham, UK, Edward Elgar, 242 p.

Kersting N., Vetter A. (dir.), 2003. Reforming local government in Europe: closing the gap between democracy and efficiency, Urban and Regional Research International 4, Wiesbaden, Springer Fachmedien, 349 p.

LE Galès P., 1995. European cities: social conflicts and governance, Oxford, Oxford University Press, 328 p.

Leitrim Business.ie, 2016. Leitrim contract for LEADER programme 2014-2020, [http:/www.leitrimbusiness.ie/Events/ ArtMID/633/ArticleID/159/Leitrim-Contract-for-LeaderProgramme-2014-2020-Signed], downloaded 20 September 2016.

Leitrim Integrated Development Company, 2007. Rural development plan 2006-2013, 133 p. [http://www.housing.gov.ie/sites/ default/files/migrated-files/en/Community/RuralDevelopment/ PublicationsDocuments/FileDownLoad\%2C41619\%2Cen.pdf], downloaded 20 september 2016.

McDonagh J., 2001. Renegotiating rural development in Ireland, Aldershot, Ashgate, $235 \mathrm{p}$.

Moseley M.J., 2003. Local partnerships for rural development: the European experience, Wallingford, CABI, 210 p.

Moseley M.J., Cherrett T., Cawley M., 2001. Local partnerships for rural development: Irish experience in context, Irish Geography, 34, n² 2, p. 176-193.

NESC (National Economic and Social Council), 1994. New approaches to rural development, Dublin, NESC, 263 p.

O'Donnell R., 2008. The partnership state: building the boat at sea, in Adshead M., Kirby P., Millar M. (dir.), Contes- ting the state: lessons from the Irish case, Manchester, Manchester University Press, p. 73-99.

O'Keeffe B., 2009. Regional and local devolution in Ireland: the potential of LEADER partnerships to provide municipal government, Lex Localis - Journal of Local Self-Government, 7, no 3, p. 257-269.

O'Keeffe B., 2014. Supporting enterprise development in rural areas, in O’Donoghue C., Conneely R., Frost D., Heanue K., Leonard B., Meredith D. (dir.), Rural economic development in Ireland, Athenry, Teagasc Rural Economy Research Centre, p. 429-453.

OECD (Organisation for Economic Co-Operation and Development), 1990. Partnerships for rural development, Paris, OECD, $155 \mathrm{p}$.

OECD (Organisation for Economic Co-Operation and Development), 2006. The new rural paradigm: policies and governance, Paris, OECD, $168 \mathrm{p}$.

Pemberton S., Goodwin M., 2010. Rethinking the changing structures of rural local government- state power, rural politics and local political strategies?, Journal of Rural Studies, 26, no 3, p. 272-283.

Pobal, 2007. Annual report and accounts, Dublin, Pobal.

Quinn B., 2015. Local government reform - plus ça change, plus c'est la même chose?, Administration, 63 n 2, p. 7-29.

Rose N., 1996. The death of the social? Re-figuring the territory of government, Economy and Society, 25, nº 3, p. 327-356.

Storey D., 1999. Issues of integration, participation and empowerment in rural development: the case of LEADER in the Republic of Ireland, Journal of Rural Studies, 15, $\mathrm{n}^{\circ} 3$, p. 307-313.

Swyngedouw E., 2005. Governance, innovation and the citizen: the Janus face of governance beyond the state, Urban Studies, 42, no 11, p. 1991-2006.

Swyngedouw E., Moulaert F., Rodriguez A., 2002. Neoliberal urbanization in Europe: large-scale urban development projects and the new urban policy, Antipode, 34, n 3 , p. $542-577$.

Turock I., 2001. Innovation in local governance: the Irish partnership model, in OECD (Organisation for Economic Cooperation and Development), Local partnership for better governance, Paris, OECD, p. 135-173.

Varley T., Curtin C., 2006. The politics of empowerment: power, populism and partnership in rural Ireland, The Economic and Social Review, 37, n ${ }^{\circ} 3$, p. 423-446.

Walsh J., 2003. Catalysts for change: public policy reform through local partnership in Ireland, in GedDes M., Benington J. (dir.), Local partnerships and social exclusion in the European Union: new forms of local social governance?, London, Routledge, p. 111-133.

Woods M., Goodwin M., 2003. Applying the rural: governance and policy in rural areas, in Cloke P. (dir.), Country visions, Harlow, Prentice Hall, p. 245-262. 